\title{
Faktor Penentu Donor untuk Berwakaf: Sebuah Eksplorasi Wakaf dalam Literatur
}

\section{Determinants of Donors for Waqf: Exploration Waqf from Literature Insight}

\author{
Gustina $^{1}$, Vera Pujani ${ }^{2}$, Yulia Hendri Yeni ${ }^{3}$, Mohamad Fany Alfarisy ${ }^{4}$ \\ ${ }^{1}$ Mahasiswa PDIM (Program Doktor Ilmu Manajemen), Universitas Andalas Padang, Indonesia, \\ umikhazid@gmail.com \\ ${ }^{2}$ Jurusan Manajemen, Universitas Andalas Padang, Kampus Limau Manis, Indonesia, \\ verapujani@eb.unand.ac.id \\ ${ }^{3}$ Jurusan Manajemen, Universitas Andalas Padang, Kampus Limau Manis, Indonesia, \\ yhyeni@yahoo.com \\ ${ }^{4}$ Jurusan Manajemen, Universitas Andalas Padang, Kampus Limau Manis, Indonesia, \\ mfany@eb.unand.ac.id
}

\begin{abstract}
The purpose of this study was to determine the factors that influence donors in giving waqf. In addition, it also gives consideration to decision makers related to waqf in Indonesia. The method in this study is a qualitative research with a description of previous research, through secondary data obtained from scientific journals, websites, books, and other electronic media sources related to the study discussed. The journals reviewed are journals published from 2012-2021. The theories discussed in this study are TRA and TPB. The findings of this study indicate that the factors of religiosity, attitude, subject norm, and convenience have a significant positive effect on the amount of waqf issued by donors or waqif (waqf givers). Through this study, it is hoped that this will become a consideration, especially for writers, as well as readers, and recommendations for waqf institutions to increase the convenience of the waqf system. In addition, the government (as a policy maker) should support waqf givers to continue to participate in this waqf practice for the good and welfare of the ummah.
\end{abstract}

Keywords: Attitude, religiosity, TPB, TRA, waqif.

\begin{abstract}
Abstrak. Tujuan penelitian ini adalah untuk mengetahui faktor-faktor yang memengaruhi donor dalam memberikan wakafnya. Selain itu juga memberikan pertimbangan kepada pembuat keputusan yang terkait dengan wakaf di Indonesia. Metode dalam penelitian ini adalah penelitian kualitatif dengan deskripsi atas penelitian sebelumnya, melalui data-data sekunder yang diperoleh dari jurnal ilmiah, website, buku, dan sumber media elektronik lainnya yang terkait dengan kajian yang dibahas. Jurnal yang direviu adalah jurnal yang terbit dari 2012-2021. Teori yang dibahas dalam penelitian ini adalah TRA dan TPB. Hasil temuan dari penelitian ini menunjukkan bahwa faktor religiosity, attitude, subject norm, dan convenience berpengaruh positif signifikan terhadap besarnya jumlah wakaf yang dikeluarkan oleh donor atau wakif (pemberi wakaf). Melalui kajian ini diharapkan hal ini menjadi pertimbangan terutama bagi penulis, juga pembaca dan rekomendasi bagi lembaga wakaf untuk meningkatkan convenience dari sistem wakaf itu. Selain itu pemerintah (sebagai pembuat kebijakan) agar mendukung para pemberi wakaf untuk terus berpartisipasi dalam amalan wakaf ini demi kebaikan dan kesejahteraan umat.
\end{abstract}

Kata kunci: Religiusitas, sikap, TPB, TRA, wakif.

\section{PENDAHULUAN}

Konsep memberi atau berdonasi sudah populer sejak lama dan merupakan bagian dari konsep kedermawaan (Teah et al., 2014). Dalam hal donasi tersebut, sudah banyak studi yang dilakukan. Masyarakat berdonasi sebagai bentuk partisipasi/kontribusinya untuk membantu orang yang kurang beruntung (Cheung dan Chan, 2000). Donasi juga merupakan bentuk kepedulian terhadap orang lain (Otto dan Bolle, 2011). Dalam Islam, berdonasi merupakan bagian dari salah satu perwujudan kehambaan (menunaikan kewajiban keagamaan). Tidak hanya Muslim, berdonasi juga didorong oleh sistem budaya, agama dan beberapa faktor pribadi (Ranganathan dan Henley, 2008). 
Menurut Saad et al. (2013), dalam Islam dikenal wakaf (salah satu bentuk donasi) yang merupakan salah satu tool yang sangat powerful untuk membiayai berbagai kegiatan sosial kemasyarakatan. Selain itu, saat ini wakaf juga bisa dijadikan salah satu ikhtiar untuk investasi yang dapat dikembangkan untuk mendanai kegiatan perekonomian (Hasan dan Abdullah, 2008). Penelitian terkait wakaf, khususnya cash waqf belum banyak dipublikasikan. Malaysia adalah salah satu negara yang sudah banyak melakukan kajian ini. Di antaranya Duasa dan Thaker (2016), Ismail dan Gazali (2019), Shamsudin et al. (2015), Mohsin (2013), Thaker dan Asmy (2018), Ambrose et al., (2018). Sedangkan kajian serupa untuk Indonesia masih langka, di antara nya yang penulis temukan adalah Nizar (2014), Faradis (2015), Niswah et al. (2020), dan Alifiandy dan Sukmana (2020).

Cash waqf merupakan sebuah revitalisasi bentuk wakaf dari yang biasanya dalam bentuk tanah atau bangunan. Dari kesepatakan jumhur ulama, mereka membolehkan cash waqf karena uang tidak habis manfaatnya setelah diinvestasikan. Untuk hal ini, Indonesia melalui Majelis Ulama Indonesia (MUI) mengeluarkan Fatwa No. 29/2002 tentang cash waqf. Dengan demikian, melalui ketetapan MUI tersebut dinilai bahwa cash waqf lebih fleksibel karena beberapa alasan:

1. Wakif (pemberi wakaf/donor) boleh berwakaf dalam jumlah kecil (tidak mesti besar seharga sebidang tanah atau bangunan) sehingga membuka peluang yang besar bagi setiap orang untuk menunaikannya secara lebih mudah.

2. Cash waqf lebih mudah dimanfaatkan sesuai tujuan yang ingin dicapai oleh si pemberi wakaf selama tidak melanggar batasan yang telah dibuat oleh syariat.

3. Sehubungan dengan kajian intensi donor wakaf untuk merealisasikan donasinya, maka mengetahui faktor-faktor yang memengaruhi keinginan dan minat donor/pemberi wakaf (wakif) adalah sebuah hal yang penting saat ini.

Selain ketepatan MUI yang mendukung untuk mendapatkan cash waqf lebih fleksibel, alasan lain penelitian ini dilaksanakan adalah Indonesia merupakan termasuk berpenduduk Muslim besar di dunia (Kusnandar, 2019) sehingga memiliki potensi yang sangat besar untuk dapat mengumpulkan cash waqf ini sehingga nanti dapat difungsikan (Otto dan Bolle, 2011; Cheung dan Chan, 2000).

Adapun tujuan studi ini adalah:

1. Mengetahui faktor-faktor yang mendorong donor/pemberi untuk menunaikan cash waqf, sehingga diketahui mana yang perlu dikembangkan dan ditingkatkan sehingga menjadi daya tarik yang lebih baik bagi pendonor nantinya.

2. Memperkaya khazanah literatur reviu di bidang perwakafan di Indonesia.

3. Sebagai alat pertimbangan pengambil keputusan bagi stakeholder terkait perwakafan di Indonesia sehingga manfaat wakaf dapat terasa lebih banyak dan lebih luas.

\section{TINJAUAN PUSTAKA}

Bagian ini akan membahas konsep dasar dan teori yang relevan terhadap perwakafan. Selain itu, diskusi konseptual ini juga menjelaskan tentang konsep perilaku memberi dan teori TRA (Theory of Reasoned Action) atau TPB (Theory of Planned Behaviour).

\section{Konsep dan Urgensi Wakaf}

Wakaf berasal dari bahasa Arab yang berarti menahan atau mencegah. Dalam Undang-Undang Wakaf Indonesia No. 41/2004 dinyatakan bahwa wakaf merupakan perbuatan hukum wakif (pemberi wakaf) untuk memisahkan dan/menyerahkan sebagian kekayaan untuk digunakan selamanya atau untuk jangka waktu tertentu sesuai dengan minatnya untuk beribadah dan/atau kesejahteraan umum sesuai syariah. Dalam Alifiandy dan Sukmana (2020), dinyatakan bahwa harta kekayaan umat Islam yang dapat digunakan untuk memberikan kemaslahatan kepada masyarakat pada umumnya, sedangkan pokoknya tidak berkurang atau ditahan selamanya. Secara spesifik Al- 
Qur'an tidak menyebutkannya dengan wakaf, namun para ulama sepakat sedekah yang terus menerus (menjadi amal jariah) yang disebut Nabi sama dengan wakaf.

Taufiq (2013) menyebutkan beberapa rukun syarat wakaf, yaitu:

1. Pemberi wakaf/donor/ sering disebut wakif.

2. Aset yang akan disumbangkan sebagai wakaf (mauquf)

3. Penerima manfaat wakaf (mauquf alaih)

4. Akad wakaf (siqhat)

Terkait dengan manfaat mengenalkan wakaf ke masyarakat umum, Alifiandy dan Sukmana (2020) menyebutkan setidaknya ada empat manfaat yang diterima. Pertama, wakaf merupakan bentuk tanggung jawab dan kepedulian terhadap sesama masyarakat (Cheung dan Chan, 2000; Otto dan Bolle, 2011). Kedua, adanya dukungan moral terhadap wakif/pemberi wakaf karena manfaat secara spiritual menjadi abadi walaupun wakif telah meninggal. Ketiga, memperbesar akumulasi kekayaan yang dapat digunakan untuk pengeluaran guna menunjang kebutuhan masyarakat umum/umat (Alpay dan Haneef, 2015; Raissouni, 2001). Keempat, wakaf dapat menjadi sumber dana yang dapat mendukung peningkatan kualitas hidup masyarakat melalui penyediaan kesehatan, pendidikan, pendapatan generasi, dll (Raissouni, 2001).

Kahf (1999) menyebutkan bahwa harta wakaf yang diberikan masyarakat sering kali dalam bentuk harta tidak bergerak (contoh tanah dan bangunan). Ini sering disebut wakaf konvensional. Namun wakaf juga dapat diberikan dalam bentuk lain seperti uang tunai (saat ini disebut cash waqf). Untuk penjelasan cash waqf ini sudah dikuatkan dengan Fatwa No. 29/2002 tentang cash waqf. Cash waqf merupakan bentuk revitalisasi dari wakaf konvensional yang lebih efektif dari segi penggunaannya. Dari penjelasan tersebut, terlihat bahwa pada dasarnya wakaf memiliki manfaat yang sangat luar biasa dan dapat dipenuhi dengan lebih baik oleh semua Muslim.

\section{Konsep Perilaku Pemberi, Teori TRA dan TPB}

Perilaku memberikan sesuatu atau menyumbang dengan sukarela merupakan amal atau kegiatan tanpa pamrih kepada orang lain yang membutuhkan. Perilaku memberi dengan sukarela ini merupakan bagian dari konsep altruism (Teah et al., 2014) dan merupakan keinginan untuk meningkatkan kesejahteraan orang lain (Otto dan Bolle, 2011). Selain itu, Kashif et al. (2015) juga menyatakan bahwa kegiatan amal atau donasi tersebut diyakini dapat membantu orang lain yang membutuhkan pada saat pemerintah tidak dapat menyediakan kebutuhan tersebut.

Anjuran untuk beramal baik dan berdonasi ini tidak hanya dianjurkan Islam, namun juga di semua agama dan kepercayaan (Ranganathan dan Henley, 2008). Sehingga tujuan dari amalan baik dan donasi tersebut adalah memberikan manfaat bagi kehidupan sosial masyarakat.

TRA (Theory of Reasoned Action) dikembangkan oleh Fishbein dan Ajzen (1975) yang merupakan teori populer di bidang sosio-psikologi yang banyak digunakan untuk meneliti niat perilaku. Teori ini banyak digunakan dalam berbagai penelitian seperti Kasri dan Ramli (2019), Ramayah et al. (2009), Duasa dan Thaker (2016), Razak dan Abduh (2012), (Pitchay et al. (2015) dan lainnya yang digunakan untuk mengukur niat perilaku orang.

Berdasarkan Ajzen dan Fishbein (1980), faktor-faktor yang memengaruhi perilaku seseorang adalah norma dan sikap subjektif, melihat niat apakah seseorang akan melakukan suatu tindakan atau tidak. TRA pada dasarnya mengandalkan bahwa keputusan seseorang tergantung pada niatnya apakah harus bertindak atau tidak. Hal ini dapat terlihat dari Gambar 1 di bawah ini. 


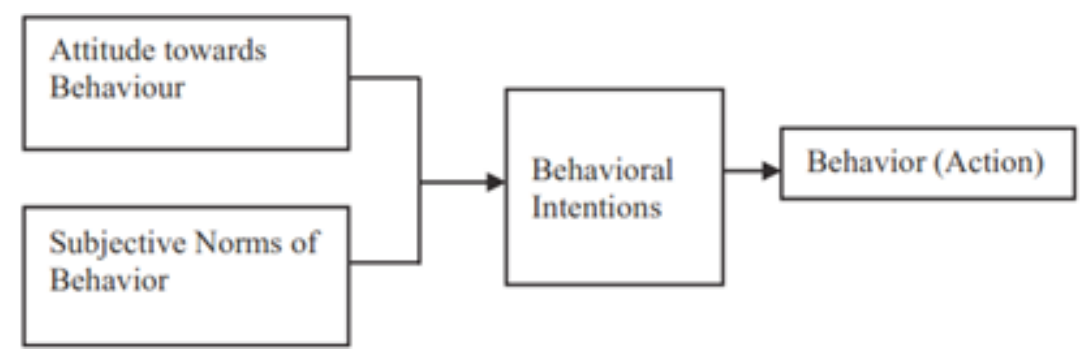

Sumber: Ajzen dan Fishbein, 1980.

Gambar 1 Framework TRA

Selain TRA, dalam psikologi sosial, juga ada teori lain yang merupakan kelanjutan TRA, yaitu TPB (Theory of Planned Behavior). TPB merupakan konsep teori yang banyak diterapkan dalam berbagai domain. Pada dasarnya TPB merupakan perpanjangan dari TRA ((Fishbein dan Ajzen, 1975; Ajzen dan Fishbein, 1980). Hal ini disebabkan karena keterbatasan TRA menangani tingkah laku yang dimiliki individu yang tidak lengkap dengan perilaku kontrol (Ajzen, 1991).

Menurut TPB, orang bertindak sesuai dengan niat dan persepsi kontrol niatnya atas perilaku mereka. Sedangkan sikap (evaluasi melakukan perilaku), norma subjektif (tekanan sosial yang dirasakan dan harapan untuk melakukan atau tidak melakukan perilaku) serta kontrol perilaku yang dirasakan (kemudahan atau kesulitan yang dirasakan melakukan suatu perilaku) memengaruhi niat (Ajzen, 1991).

Penelitian sebelumnya yang menggunakan TPB memberikan penjelasan bahwa perilaku donatur dalam mendonasikan uang dalam rangka amal dan donasi mendukung model TPB dan menyatakan bahwa sikap adalah salah satu prediktor yang penting dalam niat untuk menyumbang. Hal ini menyiratkan bahwa sikap yang lebih disukai dengan hormat perilaku (yaitu amal atau donasi), semakin menguatkan niat orang untuk melakukan perilaku tersebut sedang dipertimbangkan (Kashif et al., 2015; Shukor et al., 2019). Faktor-faktor inilah yang akan dibahas lebih lanjut dalam diskusi tulisan ini.

\section{METODE}

Untuk mencapai tujuan penelitian maka metode yang digunakan dalam penelitian ini adalah metode kualitatif dengan menggunakan kajian pustaka dan data-data sekunder yang bersumber dari penelitian sebelumnya, serta sumber data lain yang terkait dengan wakaf . Penelitian kualitatif adalah pendekatan holistik yang melibatkan penemuan. Penelitian kualitatif juga digambarkan sebagai model terungkap yang terjadi dalam pengaturan alam yang memungkinkan peneliti untuk mengembangkan tingkat detail dari keterlibatan tinggi dalam pengalaman actual (Creswell, 2018).

Adapun pengumpulan data dilakukan dengan menggali informasi dan data lainnya melalui jurnal ilmiah dan sumber-sumber media elektronik yang diterbitkan oleh institusi resmi yang kemudian dideskripsikan dengan mengutamakan karakteristik dan fenomena yang terjadi. Tujuan dari metode deskriptif adalah mendeskripsikan suatu fenomena dan karakteristiknya. Penelitian ini lebih mementingkan apa daripada bagaimana atau mengapa sesuatu terjadi (Nassaji, 2015). Artikel yang ditelusuri berada pada rentang waktu 2012-2020.

\section{HASIL DAN PEMBAHASAN}

Hasil penelusuran artikel ilmiah yang terkait dengan faktor-faktor penentu bagi donor atau wakif dalam menunaikan wakaf dari jurnal terindeks atau bereputasi masih sedikit. Topik wakaf yang dilakukan secara empiris masih tergolong langka. Dari hasil penelusuran penulis ada sekitar 12 
paper yang mengungkap faktor-faktor yang mempengaruhi donor/wakif dalam menunaikan atau mengeluarkan wakaf baik secara manual maupun secara online. Tabel berikut memuat informasi terkait artikel yang akan direviu sehubungan faktor-faktor yang dimaksud.

Tabel 1 Daftar jurnal yang direviu terkait faktor-faktor donor/wakif dalam menunaikan wakaf

\begin{tabular}{|c|c|c|c|}
\hline No. & Sitasi & Metode, konsep yang digunakan & $\begin{array}{c}\text { Temuan/faktor-faktor donor dalam } \\
\text { berwakaf }\end{array}$ \\
\hline 1. & Osman, 2014 & $\begin{array}{l}\text { Metode: Self-administered } \\
\text { questionnaires } \\
\text { Data: } 204 \text { sivitas akademika IIUM } \\
\text { Lokasi: Malaysia } \\
\text { Konsep: TPB }\end{array}$ & $\begin{array}{l}\text { Variabel digunakan: } \\
\text { Attitude, subjective norm, perceived } \\
\text { behavioural control, religiosity }\end{array}$ \\
\hline 2. & Nizar, 2014 & $\begin{array}{l}\text { Metode: Survei/ kuesioner } \\
\text { Data: } 50 \text { sampel wakif BWI } \\
\text { Lokasi: Indonesia }\end{array}$ & $\begin{array}{l}\text { Faktor yang digunakan: } \\
\text { Education level, income level, } \\
\text { mazhab, the information of media }\end{array}$ \\
\hline 3. & Faradis, 2015 & $\begin{array}{l}\text { Metode: Kuesioner } \\
\text { Lokasi: Malaysia } \\
\text { Konsep: TPB }\end{array}$ & $\begin{array}{l}\text { Faktor yang digunakan: } \\
\text { Attitude, complain, productive action, } \\
\text { equity, product characteristic, } \\
\text { reliogiosity, generosity. }\end{array}$ \\
\hline 4. & $\begin{array}{l}\text { Pitchay et al., } \\
2015\end{array}$ & $\begin{array}{l}\text { Metode: kuesioner } \\
\text { Data: } 385 \text { wakif } \\
\text { Lokasi: Klang Valley (Malaysia) } \\
\text { Konsep: TPB }\end{array}$ & $\begin{array}{l}\text { Variabel digunakan: } \\
\text { Important to intention in Islam, attitute } \\
\text { and behavioral intention, subject norm } \\
\text { and behavioral intention }\end{array}$ \\
\hline 5. & $\begin{array}{l}\text { Adeyemi et } \\
\text { al., } 2016\end{array}$ & $\begin{array}{l}\text { Metode: Kuesioner } \\
\text { Data: } 378 \text { sampel } \\
\text { Lokasi: Malaysia }\end{array}$ & $\begin{array}{l}\text { Hasil menunjukkan: } \\
\text { Level awareness wakif masih rendah, } \\
\text { kurang promosi, kurang pengetahuan }\end{array}$ \\
\hline 6. & $\begin{array}{l}\text { Mokthar, } \\
2016\end{array}$ & $\begin{array}{l}\text { Metode: Survei/ kuesioner } \\
\text { Data: } 323 \text { sampel dari } 46 \text { Responsibility } \\
\text { Centre yang ada di USM } \\
\text { Lokasi: Malaysia } \\
\text { Konsep TPB }\end{array}$ & $\begin{array}{l}\text { Variabel yang diteliti: } \\
\text { Religiosity, knowledge on waqf, } \\
\text { generosity, financial, service delivery }\end{array}$ \\
\hline 7. & $\begin{array}{l}\text { Osman dan } \\
\text { Muhammed, } \\
2017\end{array}$ & $\begin{array}{l}\text { Metode: kuesioner } \\
\text { Data: } 370 \text { wakif } \\
\text { Lokasi: Selangor Malaysia } \\
\text { Konsep: TPB }\end{array}$ & $\begin{array}{l}\text { Variabel yang diteliti: } \\
\text { Attitude, subjective norm, perceived } \\
\text { behavioral control. }\end{array}$ \\
\hline 8. & $\begin{array}{l}\text { Shukor et al., } \\
2017\end{array}$ & $\begin{array}{l}\text { Metode: Kuesioner } \\
\text { Data: } 400 \text { sampel } \\
\text { Lokasi: the Klang Valley area (Malaysia) } \\
\text { Konsep: TPB }\end{array}$ & $\begin{array}{l}\text { Variabel yang diteliti: } \\
\text { Religiosity, knowledge, convenience, } \\
\text { informative influence, trust on awqaf } \\
\text { institution. }\end{array}$ \\
\hline 9. & $\begin{array}{l}\text { Niswah et } \\
\text { al., } 2020\end{array}$ & $\begin{array}{l}\text { Metode: Online kuesioner } \\
\text { Data: } 129 \text { Muslim } \\
\text { Lokasi: Indonesia } \\
\text { Konsep: TPB dan TAM }\end{array}$ & $\begin{array}{l}\text { Variabel yang diteliti: } \\
\text { Perceived Usefulness (PU) } \\
\text { Perceived Ease of Use (PEU) } \\
\text { Perceived Behavioral Control (PBC) } \\
\text { Subjective Norm }(S N)\end{array}$ \\
\hline 10. & $\begin{array}{l}\text { Al-Harethi, } \\
2019\end{array}$ & $\begin{array}{l}\text { Metode: Survey/kuesioner } \\
\text { Data: } 100 \text { mahasiswa } \\
\text { Lokasi: Kedah, Malaysia } \\
\text { Konsep: TPB }\end{array}$ & $\begin{array}{l}\text { Variabel digunakan: } \\
\text { Religiosity, subjective norm, attitude }\end{array}$ \\
\hline 11. & $\begin{array}{l}\text { Alifiandy dan } \\
\text { Sukmana, } \\
202\end{array}$ & $\begin{array}{l}\text { Metode: Kuisioner } \\
\text { Data: } 98 \text { Muslim } \\
\text { Lokasi: Indonesia } \\
\text { Konsep: TPB }\end{array}$ & $\begin{array}{l}\text { Faktor yang digunakan: } \\
\text { Attitude, subjective norms, behavioral } \\
\text { control, knowledge }\end{array}$ \\
\hline 12. & $\begin{array}{l}\text { Shatar et al., } \\
2021\end{array}$ & $\begin{array}{l}\text { Metode: Survei } \\
\text { Data: } 218 \text { karyawan IBI (Islamic } \\
\text { Banking Institution) } \\
\text { Lokasi: Malaysia } \\
\text { Konsep: TRA }\end{array}$ & $\begin{array}{cl}\text { Hasil: } & \\
\bullet & \text { Word of mouth and trust } \\
& \text { positive significant } \\
\text { - } & \begin{array}{l}\text { Convenience and accessibility } \\
\text { significant }\end{array}\end{array}$ \\
\hline
\end{tabular}


Diskusi dan deskripsi berikut merupakan penjelasan lebih lanjut tentang artikel reviu yang telah dilakukan penulis. Beberapa hal yang dapat dilihat dari paper-paper tersebut adalah sebagai berikut:

\section{Persamaan Metode yang Dilakukan}

Dalam artikel penelitian yang dijadikan rujukan dalam paper ini, seperti Osman dan Muhammed, (2017), Pitchay et al. (2015), Shukor et al. (2017), Al-Harethi (2019), dan Shatar et al. (2021), merupakan penelitian terkait faktor-faktor pemberian wakaf yang dilaksanakan di negeri tetangga (Malaysia). Hal ini disebabkan masih langkanya publikasi yang linier. Beberapa yang dijumpai penulis seperti Nizar (2014), Niswah et al. (2020), dan Alifiandy dan Sukmana (2020). Artikel-artikel tersebut menggunakan metode yang sama, yaitu survei dengan kuisioner yang mengambil sampelnya adalah wakif/pendonor sehingga dapat diberikan kesimpulan penelitian ini dilihat dari sudut pandang pemberi wakaf.

Hal ini sesuai dengan tujuan penelitian yang dilaksanakan, yaitu menemukan faktor yang akan memengaruhi pemberi dalam melaksanakan wakaf. Penulis memang spesifik hanya mengambil artikel dengan objek khusus wakaf dan bukan objek donasi/sedekah secara umum. Hal itu disebabkan oleh dua hal, yaitu:

1. Wakaf berbeda dari sedekah/donasi/atau zakat. Zakat memiliki aturan yang tetap dalam Islam, baik untuk ukurannya (nisab) dan waktunya (haul). Penerimanya pun sudah ditentukan yaitu yang disebut 8 asnaf. Sedekah/donasi agak berbeda, boleh diberikan kapan saja dan kepada siapa saja. Hal ini jauh berbeda dengan wakaf yang memiliki persyaratan dan kriteria tertentu, seperti sifat barang wakaf ini permanen, ditujukan untuk tujuan tertentu, dan tidak boleh menghilangkan wakaf awalnya (initial waqf).

2. Pengelolaan wakaf berbeda dari zakat dan donasi/sedekah. Wakaf memiliki pengelola khusus yang disebut nazir (perorangan atau lembaga), bisa pula dalam bentuk badan wakaf/ yayasan wakaf. Pengelolaan wakaf ini mengandung unsur pengaturan untuk menyerahkan suatu benda wakaf yang bersifat kekal zatnya sehingga dapat diambil manfaatnya oleh masyarakat dalam jangka waktu. Menjaga kemanfaatan ini adalah suatu hal yang penting dalam pengelolaan wakaf, sesuai amanah wakif yang dipengaruhi oleh manajemen pengelolaan oleh nazir, kekekalan harta wakaf dan nilai manfaat yang dimiliki. Karena itu cara pengelolaan wakaf sedikit berbeda dari zakat ataupun sedekah.

Karena hal inilah, peluang untuk melakukan riset di bidang wakaf ini masih terbuka lebar. Mengingat masih banyak hal yang bisa dilihat dan dikaji, terutama terkait pengelolaannya, pemanfaatan secara finansialnya, dan keproduktifan aset wakaf tersebut.

\section{Faktor-Faktor yang Ditemukan}

Dari artikel yang direviu yang sudah dituliskan sitasinya pada Tabel 1, dapat dilihat bahwa temuan penelitian hampir sama. Banyak faktor yang memengaruhi donor/wakif dalam berwakaf ini.

1) Penelitian Osman (2014). Penelitian ini menggunakan variabel attitude, subjective norm (SN), perceived behavioral control, dan religiosity sebagai faktor yang memengaruhi donor untuk melakukan cash waqf. Dalam studi ini, attitude/sikap didefinisikan sebagai kecenderungan psikologis yang diekspresikan dari evaluasi yang menguntungkan atau tidak menguntungkan pada entitas tertentu. Secara umum, semakin baik sikap seseorang terhadap perilaku, semakin besar kemungkinan orang tersebut ingin terlibat dalam perilaku tersebut.

Sedangkan SN merupakan tekanan sosial yang dirasakan untuk melakukan sesuatu. Hal ini sangat tergantung dari persepsi individu tentang pendapat orang lain yang relevan menyangkut bagaimana melakukan sesuatu hal tersebut. Di sisi lain, variabel perceived behavioral control menurut Ajzen (1991) adalah persepsi seseorang tentang sulit atau mudahnya melakukan suatu perilaku yang disukai. Dikatakan bahwa semakin disukai sikap dan SN yang berkorelasi dengan 
suatu perilaku, dan semakin besar perilaku kontrol yang dirasakannya, maka semakin kuat niat individu untuk melakukan perilaku itu.

Muslim dengan tingkat religiusitas yang lebih tinggi diyakini akan lebih religius dan niat mereka untuk berpartisipasi dalam skema wakaf tunai lebih kuat daripada yang lain. Dari kuesioner yang menggunakan sampel berupa young intellectuals (kaum muda baik staf maupun mahasiswa) di IIUM, diperoleh hasil yang linier dengan studi sebelumnya.

Hasil studi menunjukkan bahwa attitude berpengaruh signifikan terhadap partisipasi kaum muda dalam memberikan wakaf. Demikian pula dengan variabel SN, perceived behavioral control dan religiosity berpengaruh signifikan terhadap partisipasi donor untuk menunaikan wakaf. Kajian ini termasuk pionir dalam memahami faktor-faktor yang berkontribusi terhadap penerimaan wakaf tunai di Malaysia.

Penelitian ini telah memvalidasi penerapan TPB untuk cash waqf. Adapun kontribusi dari studi ini adalah penerapan TPB dalam wakaf tunai berbeda dengan sistem yang diteliti sebelumnya, namun hasilnya menunjukkan bahwa sikap dan norma subjektif sebagai anteseden yang signifikan dari niat untuk berpartisipasi dalam wakaf tunai. Adanya hubungan langsung yang signifikan antara kontrol perilaku yang dirasakan dan niat perilaku sehingga studi ini memperluas generalisasi ini ke partisipasi wakaf tunai.

2) Penelitian Nizar (2014). Studi ini menggunakan variabel bebas berupa tingkat pendidikan, level pendapatan, mazhab dan media informasi yang digunakan. Sedangkan variabel terikatnya adalah persepsi wakaf tunai (berpartisipasi dalam wakaf tunai). Dengan menggunakan 50 sampel wakif yang berasal dari BWI, diperoleh hasil sebagai berikut:

a. Tingkat Pendidikan berpengaruh positif dan signifikan, artinya level pendidikan ini sangat perpengaruh terhadap mau tidaknya donor/wakif dalam menunaikan wakaf tunai.

b. Tingkat pendapatan, naiknya pendapatan semakin meningkatkan penerimaan terhadap partisipasi wakaf tunai ini, namun tidak cendrung signifikan.

c. Mazhab, tidak berpengaruh.

d. Media informasi, tidak berpengaruh. Baik yang menerima informasi wakaf tunai atau tidak menerima hasilnya hampir sama.

Karena hanya variabel pendidikan yang positif dan signifikan, maka implementasinya adalah nazir (pengelola) BWI harus terus meningkatkan literasi /edukasi tentang wakaf tunai ini kepada masyarakat baik secara formal (melalui sekolah) ataupun informal (melalui pengajian di surau atau masjid). Sedangkan faktor lain yang belum signifikan harus terus diupayakan.

3) Penelitian Faradis (2015). Penelitian ini berbeda dari penelitian sebelumnya dengan menggunakan variabel yang tidak biasa (cenderung melihat dari sisi pemasaran), yaitu faktor complain (ketidaknyamanan terhadap wakaf tunai), factor productive action (nilai produktif wakaf tunai), equity factor (faktor kepemilikan pendonor), product characteristic factor (karakteristik produk berupa wakaf tunai tersebut), attitude, religiosity and generosity (khusus yang 3 terakhir mirip dengan penelitian sebelumnya). Penelitian yang diadakan di Indonesia ini agak unik. Dengan tidak menuliskan berapa data/sampel yang digunakan, agak sulit bagi pembaca untuk menentukan, apakah faktor ini layak untuk diujikan. Karena di dalam paper ini sangat sedikit informasi terkait variabel-variabel yang digunakan dan juga metode serta analisis yang digunakan. Jika membandingkan dengan penelitian/studi sebelumnya yang direviu, studi ini kurang cocok untuk dijadikan referensi berikutnya.

4) Penelitian Pitchay et al. (2015). Penelitian ini menghasilkan temuan faktor-faktor yang memengaruhi perilaku Muslim untuk berwakaf adalah intention to Islam, attitute dan subject norm. Berikut adalah kerangka teori yang dipakai: 


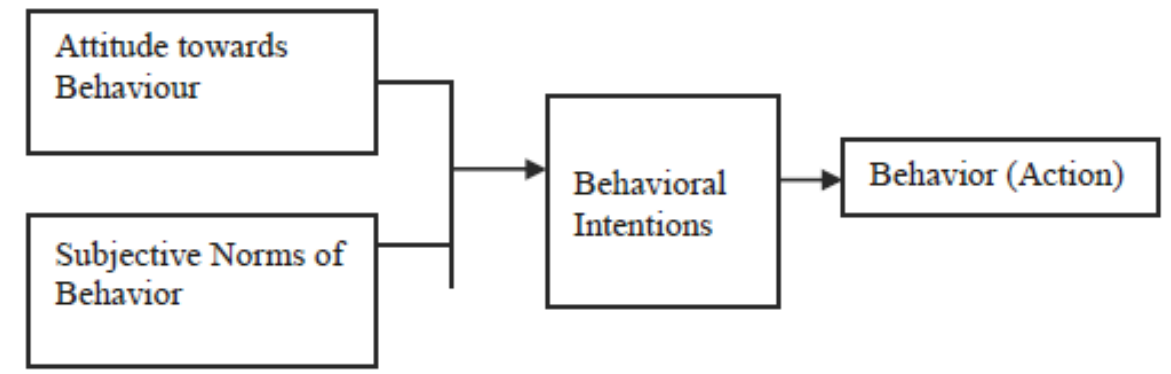

Sumber: Pitchay et al., 2015.

Gambar 2 Kerangka penelitian Pitchay et al.

Kerangka ini sama dengan kerangka yang diberikan oleh Fishbein dan Ajzen (1975). Intention to Islam berarti niat berIslam yang sangat penting maknanya. Adanya niat untuk melaksanakan syariat Islam secara keseluruhan. Diulas dalam artikel, niat ini selalu akan melandasi seseorang terutama Muslim untuk melakukan perilaku kebajikan, termasuk dalam hal ini menunaikan wakaf.

Kemudian, attitude toward behavior menuju behavioral intention menunjukkan adanya sikap yang akan menuntun ke niat perilaku untuk segera melaksanakan (action). Dalam penelitian Pitchay et al. (2015) dikutip pemahaman Ajzen dan Fishbein (1980). Sikap diartikan sebagai faktor yang menentukan sejauh mana seorang individu memiliki penilaian baik atau buruk terhadap suatu perilaku tertentu. Lebih lanjut dinyatakan pula bahwa sikap menentukan perilaku keyakinan yang melibatkan evaluasi konsekuensi atau hasil dari perilaku tertentu.

Hasil dari sikap dipengaruhi oleh keyakinan yang derajat penilaiannya didasarkan pada evaluasi hasil. Pitchay et al. (2015) memberikan preposisi bahwa sikap berpengaruh signifikan terhadap niat perilaku pegawai Muslim dalam menyumbang wakaf tunai melalui pemotongan penghasilan/gaji. Faktor ini berpengaruh positif signifikan. Oleh karena itu, berdasarkan hasil yang signifikan ini, lembaga wakaf disarankan untuk fokus pada bagaimana menciptakan program-program kepedulian yang akan mendorong motivasi para pegawai Muslim untuk berpartisipasi dalam kegiatan sukarela baik dengan memberikan uang tunai maupun sumbangan fisik.

Selanjutnya, faktor berikut adalah subject norm menuju ke behavioral intention yang memberikan makna bahwa norma subjectif akan menuntun ke niat perilaku untuk segera melaksanakan (action) wakaf tersebut. Pitchay et al. (2015) mengungkapkan dalam penelitiannya bahwa menurut Ajzen (1991), norma subjektif atau norma sosial telah digambarkan sebagai tekanan sosial yang dirasakan yang diterapkan pada keputusan individu untuk bertindak atau tidak bertindak. Ini berarti bahwa seseorang dapat bertindak karena cara orang lain berpikir bahwa tindakan tersebut penting bagi mereka.

Menurut TRA, tekanan untuk bertindak dapat dilakukan oleh orang lain seperti orang tua, kerabat, guru, dll. (Ajzen dan Fishbein, 1980). Pada beberapa kesempatan, seseorang terikat untuk mematuhi karena pengaruh orang lain. Pitchay et al. (2015) memberikan preposisi norma subjektif berpengaruh signifikan terhadap niat perilaku pegawai beragama Islam untuk berkontribusi wakaf tunai melalui pengurangan pendapatan kerja/gaji dan hasilnya menunjukkan positif signifikan.

Hal ini memberikan implikasi bahwa persepsi masyarakat yang ada di sekitar karyawan Muslim yang menjadi sampel seperti orang tua, saudara, teman sebaya, pasangan, ustaz, tetangga, dan lingkungan secara umum memegang peranan penting dalam memengaruhi niat karyawan Muslim untuk berkontribusi wakaf uang dari pendapatan kerja. Sebagai tindakan berikutnya lembaga wakaf perlu memahami bahwa niat karyawan Muslim untuk berkontribusi pada wakaf tunai dari pendapatan kerja dipengaruhi secara signifikan oleh norma subjektif. Lembaga wakaf 
harus mempertimbangkan upaya intensifikasi program penyadaran yang dapat membantu menyadarkan masyarakat dan mendorong budaya kontribusi wakaf uang di kalangan umat Islam.

5) Penelitian Adeyemi et al. (2016). Faktor yang digunakan adalah tingkat kesadaran wakaf tunai, tingkat pemahaman atau knowledge, faktor pemasaran dan promosi, dan disposisi sosial budaya tentang wakaf tunai. Penelitian yang dilaksanakan di Malaysia ini menggunakan sampel sebanyak 378. Dari penelitian ini diperoleh hasil sebagai berikut:

a. Tingkat kesadaran masyarakat untuk berwaqf tunai masih sangat rendah.

b. Tingkat pemahaman/knowledge, promosi dan sosial budaya berpengaruh positif dan signifikan. Artinya, ketiga faktor ini sangat menentukan keinginan donor untuk berpartisipasi dalam wakaf tunai. Melihat hal ini tentu saja menjadi pelajaran berharga bagi kita, bahwa walaupun Malaysia negara berpenduduk mayoritas Muslim, tapi ternyata tingkat kesadaran mereka untuk menunaikan wakaf tunai masih rendah.

Hal ini dipicu oleh keinginan yang masih tinggi untuk berwakaf dalam bentuk tanah dan benda tetap lainnya. Kemudian sebagai implikasinya, studi ini memberikan saran bahwa nazir (pengelola/ yayasan wakaf) harus lebih kreatif, menarik dan interaktif dalam hal program edukasi. Hal ini tentu untuk meningkatkan pengetahuan tadi sehingga kesadaran untuk berwakaf tunai menjadi meningkat. Selain itu dalam hal promosi dan sosial, nazir juga harus mengombinasikan dengan teknologi yang lebih efektif dan efisien misalnya dengan menggunakan sosial media, dan juga menggunakan metode pembayaran online yang lebih dikenal dengan digitalisasi payment. Menggunakan digitalisasi ini tentu akan lebih memudahkan bagi donor untuk mendistribusikan partisipasinya kepada lembaga wakaf. Tentu saja hal ini harus didukung dengan sistem yang memadai dan tingkat keamanan yang terjamin.

6) Penelitian Mokthar (2016). Penelitian dilakukan di Malaysia dengan menggunakan data sebanyak 323 sampel dari 46 Responsibility Centre yang ada di USM (Universiti Sains Malaysia). Kuesioner dijalankan pada periode 2015, setelah satu tahun berdirinya yayasan USM. Penelitian ini menggunakan variabel/faktor berupa:

a. Religiosity, faktor ini adalah nilai yang berhubungan dengan keimanan/ kepercayaan, sesuatu yang memotivasi Muslim untuk kerangka beribadah, sehingga dengan berwakaf tunai ini merupakan bagian dari ibadah.

b. Knowledge on waqf berhubungan dengan memiliki pengetahuan tentang sesuatu, keinginan akan muncul pada hal itu. Pengetahuan dan pemahamanini berkaitan dengan tingkat pendidikan terutama di Malaysia, mayoritas Muslim hanya mengenal wakaf berupa fixed asset seperti tanah dan bangunan. Sedikit pengetahuan tentang wakaf tunai ini. Inilah salah satu alasan untuk diujikan.

c. Generosity/altruism. Kedermawanan atau altruisme adalah kebaikan yang tulus dalam memberi, bukan karena ingin mendapatkan balasan/manfaat dari membantu tersebut. Pernyataan model altruisme memiliki daya prediksi yang rendah karena kedermawanan mungkin dipengaruhi oleh altruisme bersyarat (altruisme tidak murni). Namun penggunaan kedermawanan dalam konsep ini serupa dengan konsep norm/moral yang ada pada TPB.

d. Financial, faktor ini merupakan salah satu faktor yang paling banyak digunakan sebagai variabel dalam penelitian sebelumnya. Hal ini wajar karena jumlah partisipasi donor tentu akan ditentukan banyaknya finansial yang dimilikinya.

e. Service delivery, faktor ini adalah bagaimana cara mendistribusikan wakaf tunai tadi. Hal ini dapat dilihat dari jenis pembayarannya atau jasa lainnya yang disediakan oleh nazir/lembaga wakaf untuk para donator. Artinya kemudahan yang bisa diterima oleh donatur dalam melaksanakan wakaf ini dalam rangka mereka beribadah tersebut.

Dengan konsep TPB yang digunakan, penelitian ini menemukan beberapa hasil sebagai berikut:

a. Faktor religiosity adalah paling kuat/signifikan dalam memengaruhi niat para pendonor (Muslim staf USM) untuk melakukan wakaf tunai. 
b. Karena keterbatasan pengetahuan donatur tentang wakaf tunai, maka program wakaf ini belum terlalu populer sehingga sebagi implikasinya pihak manajemen USM harus meningkatkan literasi/ edukasi terhadap pemahaman wakaf ini di kalangan organisasinya, memberikan promosi (seperti layaknya strategi dalam pemasaran) sebagai motivasi untuk berwakaf tunai, misalnya dengan cara menggunakan channel media sosial, juga menggunakan tokoh ulama yang sangat dipercaya. Dengan demikian diharapkan dapat meningkatkan jumlah wakaf yang diperoleh.

c. Staf Muslim USM tertarik dengan pendekatan counter untuk melakukan wakaf tunai. Maka staf Muslim USM tertarik dengan pendekatan counter untuk melakukan wakaf tunai. Kedua faktor utama ini, religiositas dan pelayanan, perlu menjadi sorotan untuk pengetahuan manajemen USM untuk meningkatkan pengumpulan wakaf tunai USM di masa depan yang lebih baik.

7) Penelitian Osman dan Muhammed (2017). Penelitian ini menyatakan bahwa faktor-faktor tersebut adalah attitude (sikap), subjective norm (norma subjektif), perceived behavioral control (persepsi kontrol keperilakuan). Attitude dalam bahasannya ditujukan pada sikap/perbuatan yang memiliki landasan pendirian. Selanjutnya, norma subjektif merupakan persepsi seseorang mengenai tekanan sosial untuk melakukan atau tidak melakukan perilaku (sesuatu yang diyakini oleh seseorang untuk berbuat sesuatu yang melandasi atau memotivasi) unutk bertindak. Sedangkan persepsi kontrol keperilakuan mengacu kepada persepsi seseorang terhadap sulit tidaknya melaksanakan perilaku yang diinginkan, terkait dengan keyakinan akan tersedia atau tidaknya sumber dan kesempatan yang diperlukan untuk mewujudkan perilaku tertentu (Ajzen, 2005). Untuk niat, dimaknai dengan keinginan untuk melakukan sesuatu yang diikuti dengan perbuatan. Dalam penelitiannya Osman memberikan kerangka seperti ini:

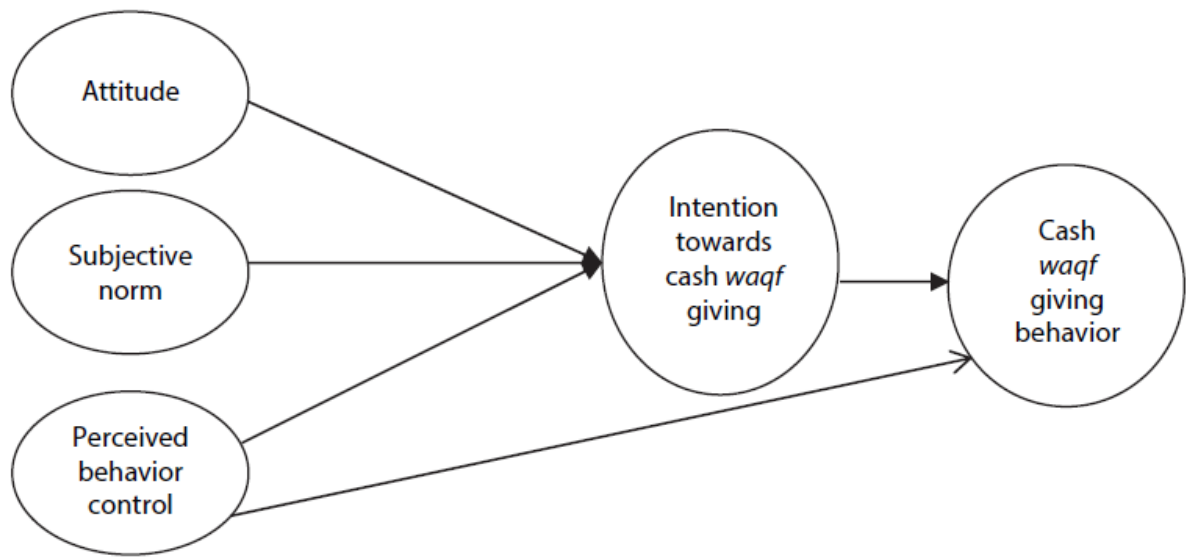

Sumber : Osman dan Muhammed, 2017.

Gambar 3 Kerangka penelitian Osman dan Muhammed

Dari kerangka ini terlihat bahwa ada tiga faktor yang ada (attitude, subjective norm dan perceived behavior control) yang memengaruhi intention toward (niat untuk berbuat) yang akan menjadi perilaku memberi (cash waqf giving behavior). Hasil Penelitian ini linier dengan teori Ajzen (2005). Hasil temuan di sini menunjukkan faktor yang diteliti tersebut sangat signifikan menjelaskan perilaku pemberian wakaf tunai di Malaysia, khususnya di Selangor Darul Ehsan. Sebagai implikasinya adalah para nazir, pemerintah (pembuat kebijakan) harus membuat strategi relevan dan perencanaan fundraising untuk mempromosikan action wakaf tunai tersebut. Mereka harus melakukan edukasi secara berkelanjutan dan serius melalui lokakarya, dialog dan lainnya kepada masyarakat Muslim, akademisi atau perusahaan dalam rangka meningkatkan terus kesadaran dan motivasi untuk berwakaf tersebut.

8) Penelitian Shukor et al. (2017). Penelitian ini memberikan hasil investigasi yang berbeda dengan menginvestigasi anteseden (faktor penentu) dan konsekuensi dari sikap Muslim terhadap partisipasinya dalam berwakaf tunai di Malaysia. Variabel yang digunakan adalah religiosity 
(religiusitas), knowledge (pengetahuan), convenience (kenyamanan), informative influence (pengaruh informatif), dan trust on awqaf institution (kepercayaan kepada lembaga wakaf). Kerangka teori yang digunakan penulis terlihat dalam gambar berikut:

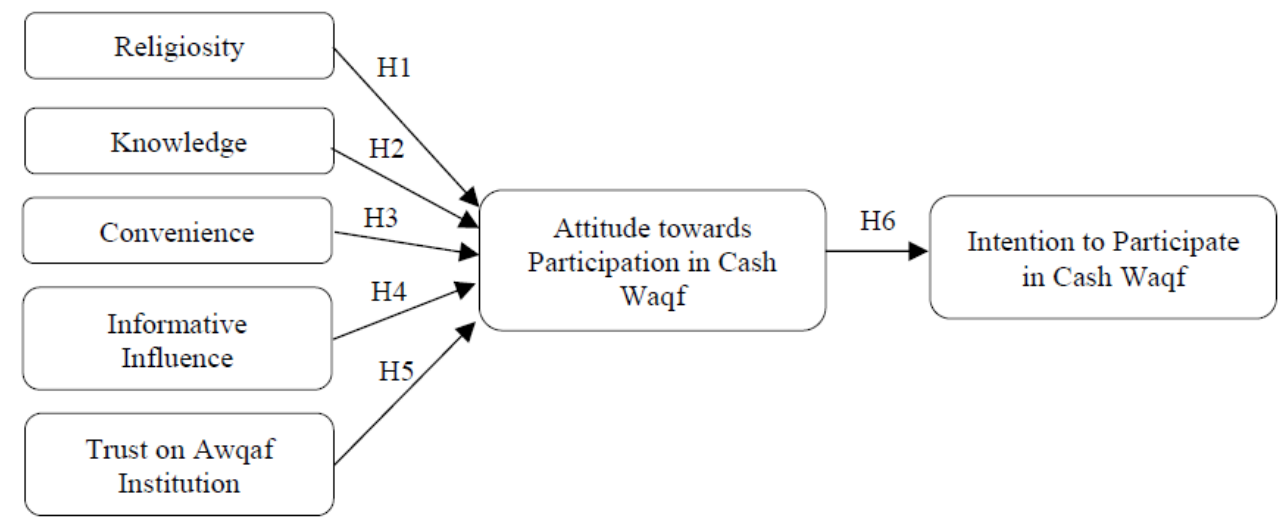

Sumber: Shukor et al., 2017.

Gambar 4 Kerangka penelitian Shukor et al.

Hasil penelitian menunjukkan setidaknya ada tiga faktor yang berpengaruh positif signifikan, yaitu religiosity, trust on awqaf institution dan convenience. Religiositas berhubungan positif dengan sikap individu terhadap wakaf uang. Ini menegaskan bahwa komitmen seseorang terhadap agama dapat memengaruhinya untuk berperilaku sesuai dengan ajarannya, dalam hal ini menunaikan wakaf.

Selanjutnya, penelitian ini juga menemukan bahwa sikap individu terhadap keikutsertaan dalam wakaf tunai ditentukan oleh kenyamanan dalam berkontribusi. Temuan ini menegaskan penelitian sebelumnya bahwa kenyamanan memainkan peran penting dalam pengambilan keputusan konsumen (Jih, 2007). Jika para pemberi wakaf tunai merasa ada banyak saluran bagi mereka untuk menyumbangkan wakaf tunai, hal ini akan menumbuhkan sikap yang lebih positif terhadap partisipasi dalam praktik.

Kemudian, hubungan positif antara kepercayaan pendonor/pewakif pada lembaga wakaf dan sikap individu terhadap wakaf tunai dapat menunjukkan nilai lembaga wakaf yang mengembangkan unsur kepercayaan untuk mendorong sikap positif terhadap partisipasi dalam wakaf tunai. Hal itu akan menghasilkan niat untuk memberikan wakaf tunai. Kepercayaan yang dikembangkan dalam lembaga wakaf berarti pemberi wakaf meyakini informasi yang diberikannya dan mempercayakannya untuk pengumpulan wakaf tunai.

Kepercayaan juga dapat menunjukkan kepercayaan pemberi wakaf pada lembaga wakaf sebagai lembaga yang berwenang untuk mengumpulkan wakaf tunai. Berbeda dari hasil penelitian Alifiandy dan Sukmana (2020), pengetahuan seseorang tentang konsep wakaf dan jenis wakaf belum tentu penting dalam memengaruhi sikapnya terhadap partisipasi dalam wakaf tunai. Selain itu, hasil yang tidak signifikan antara pengaruh informatif dan sikap berpartisipasi mungkin menunjukkan bahwa pengaruh orang lain tidak relevan dalam menentukan sikap individu terhadap partisipasi dalam wakaf tunai, tidak seperti jenis produk lainnya. Sikap positif terhadap keikutsertaan dalam wakaf tunai diputuskan atas dasar perbuatan baik dengan keyakinan bahwa perbuatan baik tersebut akan tertunaikan kepada orang yang berhak.

9) Penelitian Niswah et al. (2020). Penelitian ini memiliki sedikit variasi cara dan hasil temuannya. Berbeda dari penelitian sebelumnya yang direviu penulis, penelitian ini menggunakan konsep TAM (Technology Acceptance Model) selain juga konsep TPB (Theory of Planned Behavior). Adapun kerangka penelitian yang dipakainya adalah seperti gambar berikut: 


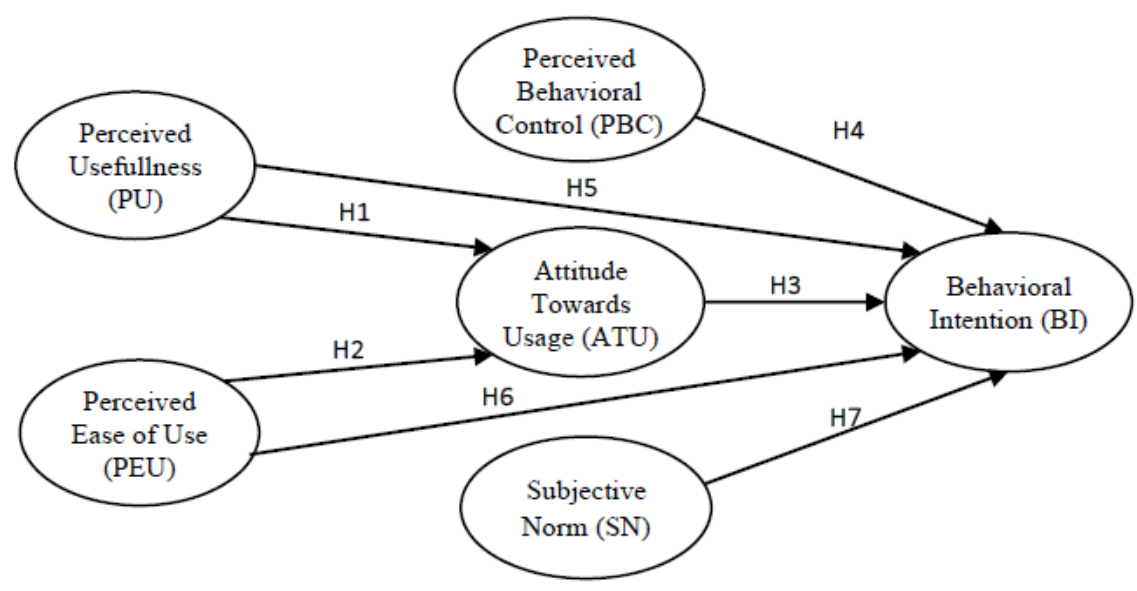

Sumber: Niswah et al., 2020.

Gambar 5 Kerangka penelitian Niswah et al.

Penelitian ini menggunakan perceived usefulness/PU (manfaat yang dirasakan), perceived ease of use/PEU (kemudahan penggunaan yang dirasakan), attitude towards usage/ATU (sikap terhadap penggunaan), perceived behavioral control/PBC (persepsi kontrol perilaku), subjective norm/SN (norma subjektif), behavioral intention/BI (niat perilaku) terhadap penggunaan fintech untuk berwakaf.

Hasil temuan penelitian ini menunjukkan bahwa PEU dan PU secara statistik berpengaruh signifikan terhadap ATU. Kemudian PU, ATU dan PEU berpengaruh signifikan terhadap BI. Sedangkan PBC, PU dan SN tidak berpengaruh signifikan terhadap BI. Studi ini menunjukkan bahwa literasi wakaf yang berbasis fintech masih terbatas. Orang-orang menggunakan fintech dalam sehari-hari masih untuk tujuan komersial saja. Potensi signifikan untuk mendorong tujuan sosial melalui fintech, terutama untuk menunaikan wakaf, masih sangat besar karena orang menggunakan internet setiap hari untuk mendapatkan informasi.

10) Penelitian Al-Harethi (2019). Penelitian dilakukan di Malaysia dengan menggunakan kuesioner yang disebarkan pada 100 mahasiswa pada sebuah universitas yang ada di Kedah, Malaysia. Penelitian ini menggunakan variabel/faktor berupa religiosity, subjective norm, dan attitude yang sesuai dengan konsep pada TPB. Hasil penelitian menunjukkan bahwa ketiga faktor menunjukkan hubungan yang signifikan terhadap partisipasi donor dalam menunaikan wakaf tunai.

Penelitian ini merujuk pada Osman dan Muhammed (2017) dengan memberikan rekomendasi untuk meningkatkan edukasi sehingga akan meningkatkan pengetahuan masyarakat baik secara formal (misalnya di sekolah) atau informal (di pengajian, masjid dll.). Pengetahuan agama yang semakin baik akan menaikkan pula keinginan Muslim untuk beribadah lewat wakaf ini. sikap baik yang semakin banyak dan dilakukan terus menerus tentu akan memengaruhi persepsi orang lain untuk juga berbuat baik. Karena itu pemerintah diharapkan dapat membuat program yang akan mendukung wakaf tunai ini dan memudahkan masyarakat untuk menyalurkannya.

11) Penelitian Alifiandy dan Sukmana (2020). Penelitian ini ditujukan untuk menginvestigasi faktor yang memengaruhi seseorang untuk menunaikan wakaf. Penelitian dilakukan pada Pusat Pengelolaan Dana Sosial (PUSPAS) Universitas Airlangga untuk mengetahui pengaruh sikap, norma subjektif, persepsi kontrol perilaku, dan pengetahuan dalam memengaruhi kemauan wakif dalam berwakaf. Variabel yang digunakan yaitu sikap terhadap perilaku (attitude), pengetahuan (knowledge), persepsi pengendalian perilaku (perceived behavioral control), dan norma subyektif (subjective norms).

Hasil penelitian menunjukkan bahawa sikap berpengaruh positif signifikan terhadap intensi wakif dalam wakaf tunai. Berdasarkan hasil penelitian, sikap ini tergantung besarnya 
penghasilan yang diterima dan besarnya keinginan untuk melakukan wakaf tersebut. Norma subjektif tidak berpengaruh signifikan terhadap kesediaan wakif. Hal ini menunjukkan dorongan lingkungan sosial dari staf dan guru (terutama yang populer) belum bersedia untuk menunaikan wakaf tunai ini atau dengan kata lain keteladanan tidak memengaruhi. Untuk faktor persepsi pengendalian perilaku juga tidak signifikan berpengaruh terhadap perilaku wakif. Responden kebanyakan tidak setuju dengan adanya pemotongan penghasilan untuk ini. Sedangkan pengetahuan berpengaruh signifikan terhadap kemauan wakif untuk berwakaf. Artinya semakin baik pemahaman dan pengetahuan wakif, semakin besar keinginan untuk melaksanakan wakaf. Implikasinya di sini menunjukkan perlunya pemerintah/pengambil kebijakan melakukan edukasi, promosi dan pemberian informasi yang baik, tepat dan benar terkait wakaf ini kepada masyarakat sehingga faktor yang belum signifikan tadi berubah ke arah positif.

12) Penelitian Shatar et al. (2021). Penelitian ini dilaksanakan dengan metode survei melalui kuesioner sampel 218 karyawan IBI (Islamic Banking Institution) yang ada di Malaysia. Konsep yang dipakai adalah TPB. Adapun faktor yang digunakan dalam studi ini:

a. Word of mouth (WOM), merupakan salah satu pendorong penting untuk mempromosikan penawaran produk atau layanan baru untuk berbagai jenis pelanggan dan untuk memengaruhi perilaku pembelian mereka. Dalam hal ini, WOM dimaksudkan adalah sesuatu hal yang dilakukan oleh nazir/lembaga wakaf untuk mendorong donatur memberikan wakafnya.

b. Trust, mengacu pada kesiapan individu untuk mengembangkan kepercayaan terhadap mitra pertukaran dalam memberikan hasil yang diinginkan seperti yang diharapkan (dalam hal ini adalah tingkat kepercayaan donatur kepada lembaga wakaf).

c. Convenience, ini dapat diterjemahkan dengan cara yang berbeda, seperti waktu, lokasi, jumlah, ketersediaan pilihan, metode pembayaran dan kemasan, atau kombinasi dari elemen-elemen tersebut. Persepsi individu tentang kenyamanan mendapatkan produk atau layanan memengaruhi penilaiannya secara keseluruhan terhadap penyedia layanan. Namun demikian, individu yang ingin berkontribusi pada lembaga wakaf tunai dapat dengan mudah melakukannya karena mereka hanya perlu memberikan sejumlah donasi tunai dan tidak diharuskan untuk memberikan lainnya.

d. Accessibility to cash waqf, hal ini sangat penting mengingat fakta bahwa individu dengan tingkat pendapatan yang berbeda bersedia untuk menyumbang. Sistem metode pembayaran sangat penting dalam menyederhanakan proses donasi dan membuatnya nyaman bagi orang lain. Lembaga dapat meningkatkan pengumpulan wakaf tunai melalui penyederhanaan proses donasi kepada donatur. Aksesibilitas yang lebih mudah dari individu untuk menyumbangkan wakaf tunai sangat penting karena memotivasi para donatur untuk berkontribusi.

Hasil penelitian menunjukkan bahwa WOM mempunyai pengaruh positif dan signifikan. IBI dapat mempertimbangkan program komunikasi pemasaran untuk mempromosikan wakaf tunai jika mereka tertarik untuk memaksimalkan jumlah kontribusi dana tunai. Trust, convenience dan accessibility to cash waqf juga mempunyai pengaruh positif dan signifikan. Hasil ini merupakan referensi yang baik bagi IBI. Donatur menghargai berbagai cara atau alat yang dapat membantu mereka untuk berdonasi ke lembaga wakaf tunai. Lembaga wakaf harus mengembangkan strategi yang lebih baik untuk menarik pemberi, selain mempromosikan dan meningkatkan anggaran wakaf tunai mereka. Lebih lanjut, IBI masih perlu meningkatkan branding dan strategi komunikasinya kepada masyarakat untuk menunjukkan bagaimana mengelola donasi wakaf tunai dan lembaga Islam yang terlibat dalam wakaf tunai ini.

\section{SIMPULAN}

Studi ini mempelajari dan mereviu artikel hasil penelitian terkait dengan faktor-faktor yang memengaruhi pendonor/wakif untuk menunaikan wakaf. Artikel yang direviu berasal dari jurnal terindeks dan juga prosiding bereputasi. Studi terkait ini masih tergolong langka (khususnya di 
Indonesia), sehingga masih terbuka peluang luas untuk melakukan penelitian berikutnya yang terhubung dengan wakaf ini, baik dari segi pengelolaan wakaf (terkait manajemen, tingkat kepercayaan), pengalokasian dana wakaf, dan lainnya.

Penulis mereviu 12 artikel terkait wakaf dengan faktor penentu yang memengaruhi donor untuk melaksanakan wakaf. Dari artikel yang direviu, ditemukan berbagai faktor yang berpengaruh tersebut, yaitu attitude (sikap), subjective norm (norma subjektif), perceived behavioral control (persepsi kontrol perilaku), knowledge (pengetahuan), religiosity (religiositas), convenience (kenyamanan), informative influence (pengaruh informatif), trust on waqf institution (kepercayaan pada lembaga wakaf), perceived easy of use (kemudahan penggunaan yang dirasakan), perceived usefulness (manfaat yang dirasakan, attitude toward usage (sikap terhadap penggunaan), dan behavioral intention (niat berperilaku). Selain itu juga ditemukan faktor lain seperti education, level of income, media, mazhab, marketing factor (productive, service delivery, promotion, word of mouth).

Tidak semua faktor berpengaruh signifikan. Namun beberapa faktor yang berpengaruh positif signifikan dan menjadi variabel/faktor yang dominan, seperti attitude, subjective norm, religiosity, convenience, dan trust, memberikan bukti empiris bahwa faktor tersebut perlu mendapatkan perhatian, terutama bagi lembaga wakaf/nazir selaku pengelola wakaf tunai yang akan diberikan oleh para pendonor.

Hasil penelitian ini menegaskan bahwa literasi wakaf masih terbatas, apalagi yang berbasis fintech. Maka dari itu, bentuk usaha nyata ke depan yang dapat dilakukan berbagai pihak terkait wakaf ini, seperti nazir (pengelola), pemerintah (pengambil keputusan), akademisi (pendidik dan lainnya), harus memiliki tekad dan semangat kuat untuk melakukan edukasi, promosi dan bentuk penyampaian informasi lainnya, sehingga literasi wakaf ini semakin baik diterima oleh masyarakat yang notabene adalah golongan terbanyak yang akan berkontribusi terhadap pelaksanaannya (dalam memberikan wakaf). Pada akhirnya, kemanfaatan wakaf juga diharapkan semakin meningkat dengan jumlah yang banyak serta pengelolaan wakaf yang semakin amanah.

Tingkat kepercayaan pendonor terhadap lembaga wakaf harus selalu dijaga dengan mengedepankan pengelolaan dan manajemen yang transparan dan terkontrol. Hasil kerja yang terukur dan dapat dipertanggungjawabkan harus juga disajikan untuk pendonor/calon wakif sehingga wakif tidak ragu untuk melaksanakan dan menunaikan tindakan wakaf ini di samping untuk memenuhi nilai nilai syariat agama.

\section{Rencana Penelitian/Studi Mendatang}

Studi tentang reviu artikel wakaf ini bermanfaat bagi pembaca dan peminat karena masih terbatasnya literatur seperti ini. Selain bermanfaat bagi penulis, diharapkan akan menambah khazanah ilmu pengetahuan tentang studi tersebut. Sebagai pertimbangan untuk penelitian ke depan ada beberapa hal yang mungkin dapat diterapkan, yaitu:

1. Jika dilaksanakan di lokasi penelitian yang unik, seperti Indonesia yang merupakan basis Muslim cukup besar, peluang ini juga akan lebih besar. Karena populasi calon wakif itu juga besar. Terutama untuk daerah-daerah tertentu, seperti Provinsi Sumatera Barat (Minang identik dengan Islam, adat bersandi syarak, syarak bersandi Kitabullah), Provinsi Aceh dan lainnya karena beberapa faktor demografinya yang sangat mendukung.

2. Hasil reviu yang ada menunjukkan faktor trust terhadap lembaga wakaf sangat berpengaruh. Untuk kajian Indonesia, faktor ini terkesan belum dibahas. Padahal untuk saat ini faktor kepercayaan (termasuk transparansi) masih terbatas dilakukan, sehingga penulis akan merekomendasikan faktor ini untuk dimasukkan dalam salah satu variabel yang akan diteliti.

3. Kajian terkait wakaf jika didampingkan dengan faktor gender juga akan menjadi sesuatu hal yang unik. Secara psikologis, perempuan berbeda dalam pengambilan keputusan, termasuk 
intensi untuk menjadi seorang filantropi. Kedermawanan perempuan dan laki laki patut pula diujikan dalam sebuah penelitian.

4. Kajian wakaf dengan menggunakan fintech untuk Indonesia, masih terbatas. Peluang untuk melaksanaan studi dengan mengikutkan faktor ini terlihat seperti sesuatu hal yang juga menjanjikan karena saat ini Indonesia termasuk negara yang memakai jaringan internet cukup besar di dunia, terutama di kalangan milenial. Kajian wakaf dengan mengikutkan faktor milenial ini juga terlihat menarik.

5. Artikel yang direvieu menggunakan metode survei dengan kuesioner. Studi ini akan semakin baik jika metode dapat dikombinasikan dengan metode interview, baik terhadap pendonor/ pemberi wakaf maupun pihak lainnya seperti nazir (pengelola/yayasan) dan pemegang kekuasaan (seperti Badan Wakaf Indonesia). Dari kombinasi keduanya, diharapkan hasil yang akan didapat lebih memperlihatkan kondisi sebenarnya, karena tidak hanya dikaji dari sudut pandang pemberi (pendonor/ pewakaf), namun juga dari sudut pandang pihak lain yang terlibat.

\section{DAFTAR PUSTAKA}

Adeyemi, A. A., Ismail, N. A. \& Hassan, S. S. (2016). An empirical investigation of the determinants of cash waqf awareness in Malaysia. Intellectual Discourse, Special Issue (2016), 501-520.

Ajzen, I. \& Fishbein, M. (1980). Understanding Attitude Predicting Social Behavior. New Jersey (USA), Prentice Hall.

Ajzen, I. (1991a). The theory of planned behavior. Journal Organizational Behavior and Human Decision Processes, 50(2), 179-211.

Al-Harethi, A. R. S. (2019). Factors Determine cash waqf participation in Kedah, Malaysia: Perception from students in Kolej University Insaniah. IKONOMIKA: Jurnal Ekonomi Dan Bisnis Islam, 4(1), $53-59$.

Alifiandy, M. M. \& Sukmana, R. (2020). The influence of planned behaviour theory and knowledge towards the waqif intention in contributing waqf. JEBIS: Jurnal Ekonomi dan Bisnis Islam, 6(2), 260-272. https://doi.org/10.20473/jebis.v6i2.22624.

Alpay, S. \& Haneef, M. (2015). Integration of Waqf and Islamic Microfinance for Poverty Alleviation: Case Studies of Malaysia, Indonesia and Bangladesh. SESRIC, IIUM, Gombak, Malaysia.

Ambrose, A. H. A. A., Hassan, M. A. G. \& Hanafi, H. (2018). A proposed model for waqf financing public goods and mixed public goods in Malaysia. International Journal of Islamic and Middle Eastern Finance and Management.

Cheung, C. \& Chan, C. (2000). Social-cognitive factors of donating money to charity, with special attention to an international relief organization. Evaluation and Program Planning, 23, 241-253.

Creswell, J. W. (2007). Designing a Qualitative Study Qualitative Inquiry and Research Design Choosing Among Five Approaches ( 2 nd ed.). California (USA), Thousand Oaks CA-SAGE.

Duasa, J. \& Thaker, M. A. (2016). A cash waqf investment model: An alternative model for financing micro-enterprises in Malaysia. Journal of Islamic Monetary Economics and Finance, 1(2), 161188.

Faradis, J. (2015). The determinants of waqf preference toward money-cash waqf. Global Review of Islamic Economics and Business, 2(3), 219-229.

Fishbein and Ajzen. (1975). Belief, Attitude, Intention and Behavior: An Introduction to Theory and Research (R. J. Hill (ed.)). Boston (USA), Addison-Wesley Publication Co.

Hasan, Z., \& Abdullah, M. N. (2008). The investment of waqf land as an instrument of Muslims' economic development in Malaysia. The Dubai International Conference on Endowments' Investment, $1-25$.

Ismail, C. M. \& Gazali, H. (2019). A conceptual framework for cash waqf with blockchain in financing education for the islamic religious school in Malaysia. $A L-I T Q \bar{A} N, 3(1), 73-88$. 
Jih, W. J. K. (2007). Effects of consumer-perceived convenience on shopping intention in mobile commerce: an empirical study. International Journal of E-Business Research, 3(4), 33-48., vol 3(No 4), pp 33-48.

Kahf, M. (1999). Financing the development of awqaf property. American Journal of Islamic Social Sciences, 16(4), 39-68.

Kashif, M., Sarifuddin, S. \& Hassan, A. (2015). Charity donation: Intentions and behavior. Marketing Intelligence \& Planning, 33(1), 90-102. https://doi.org/10.1108/MIP-07-2013-0110.

Kasri, R. A., \& Ramli, U. H. (2019). Why do Indonesian Muslims donate through mosques? A theory of planned behaviour approach. International Journal of Islamic and Middle Eastern Finance and Management, 12(5), 663-679.

Kusnandar. (2019). Indonesia, Negara dengan Penduduk Muslim Terbesar Dunia [Internet]. [diunduh pada 2021 Jun 1]. Tersedia pada: https://databoks.katadata.co.id/datapublish/2019/09/25/indone sia-negara-dengan-penduduk-muslim-terbesar-dunia.

Mohsin, M. I. (2013). Financing through cash-waqf: A revitalization to finance different needs. International Journal of Islamic and Middle Eastern Finance and Management, 6(4), 304-321.

Mokthar, M. Z. (2016). Perceptions of Universiti Sains Malaysia Muslim staff on factors influencing their intention to perform cash waqf. Journal of Islamic Studies and Culture, 4(2), 101-109.

Nassaji, H. (2015). Qualitative and descriptive research: Data type versus data analysis. Language Teaching Research, 19(2), 129-132.

Niswah, F. M., Lu'liyatul Mutmainah, F. A., Hadyantari, N., \& Huda, N. (2020). Do Indonesian Muslims have intention to participate on cash waqf through fintech?. In Proceedings of 3rd International Conference on Strategic and Global Studies, ICSGS 2019, 6-7 November 2019, Sari Pacific, Jakarta, Indonesia, 97-114.

Nizar, A. (2014). Faktor-faktor yang mempengaruhi persepsi wakif tentang wakaf uang. Esensi: Jurnal Bisnis dan Manajemen, 4(1), 21-36.

Osman, A. F. (2014). An analysis of cash waqf participation among young intellectuals. In 9th International Academic Conference, Istanbul, 13 April 2014, pp 911-723.

Osman, A. F. \& Muhammed, M. O. (2017). Measuring a cash waqf giving behavior among Muslim donor in Malaysia: A theory of planned behavior approach using structural equation modelling. The Journal of Muamalat and Islamic Finance Research, 14(2), 39-63.

Otto, P. \& Bolle, F. (2011). Multiple facets of altruism and their influence on blood donation. The Journal of Socio-Economics, 40, 558-563. https://doi.org/10.1016/j.socec.2011.04.010.

Pitchay, A. A., Meera, A. K. M., \& Saleem, M. Y. (2015). Factors influencing the behavioral intentions of Muslim employees to contribute to cash-waqf through salary deductions. JKAU: Islamic Econ, 28(1), 57-90.

Raissouni, A. (2001). Islamic Waqf Endowment: Scope and Implications. Rabat (MAR), ISESCO.

Ramayah, T., Rouibah, K., Gopi, M., \& Rangel, G. J. (2009). A decomposed theory of reasoned action to explain intention to use Internet stock trading among Malaysian investors. Computers in Human Behavior, 25, 1222-1230.

Ranganathan, S. K. \& Henley, W. H. (2008). Determinants of charitable donation intentions: A structural equation model. International Journal of Nonprofit and Voluntary Sector Marketing, 11, 1-11. https://doi.org/10.1002/nvsm.

Razak, D. A. \& Abduh, M. (2012). Customers' attitude towards diminishing partnership home financing in Islamic banking. American Journal of Applied Sciences, 9(4), 593-599.

Saad, N. M., Kassim, S., \& Hamid, Z. (2013). Involvement of corporate entities in waqaf management: Experiences of Malaysia and Singapore. Asian Economic and Financial Review, Vol 3(N0 6), 736-748.

Shamsudin, A. F., Hashim, J., Yusof, W. S. W., Yusof, A., Mohamad, S., Yusof, A. M., \& Abidin, I. Z. (2015). A conceptual model for inter-state corporate waqf financing for higher learning. Global Journal Al-Thaqafah, 5(1), 51-58.

Shatar, W. N. A., Hanaysha, J. R., \& Tahir, P. R. (2021). Determinants of cash waqf fund collection in Malaysian Islamic banking institutions: Empirical insights from employees' perspectives. 
ISRA International Journal of Islamic Finance Emerald Publishing Limited. 0128-1976 DOI 10.1108/IJIF-06-2020-0126, https://www.emerald.com/insight/0128-1976.htm.

Shukor, S., Anwar, I. F., Aziz, S. A., \& Sabri, H. (2017). Muslim attitude towards participation in cash waqf: Antecedents and consequences. International Journal of Business and Society, Vol. $18,193-204$.

Shukor, S., Johari, F., Wahab, K. A., Zulkefli, Z. K., Ahmad, N., Alias, M. H., Rahman, A. A., \& Orip, N. M. M. (2019). Trust on awqaf institutions: Evidence from Malaysia. Journal of Islamic Marketing, 10(2), 511-524.

Taufiq, T. (2013). Wakaf dalam persepektif hukum Islam. Jurnal Ilmu Pengetahuan dan Teknologi, 24(1), 62-75.

Teah, M., Michael Lwin, \& Cheah, I. (2014). Moderating role of religious beliefs on attitudes towards charities and motivation to donate. Asia Pacific Journal of Marketing and Logistics, 26(5), 738-760.

Thaker, M. T., \& Mohamed Asmy Bin. (2018). A qualitative inquiry into cash waqf model as a source of financing for micro enterprises. ISRA International Journal of Islamic Finance, 10(1), 1935. https://doi.org/10.1108/IJIF-07-2017-0013. 